\title{
PENGUASAAN KONSEP USAHA DAN ENERGI PESERTA DIDIK KELAS X DENGAN MODEL PEMBELAJARAN EKSPOSITORI BERBANTUAN ORGANIZERS
}

\author{
Dwi Gita Oktaviani*, Ahmad Harjono, I Wayan Gunada \\ Program Studi Pendidikan Fisika, Universitas Mataram \\ *Email: gita.fis2014@gmail.com
}

\begin{abstract}
Lesson material presented in the form of data or facts and specific concepts on expository learning model helps learners to connect new material with material that precedes it, so organizers help is provided to instill meaningful learning. This study aims to determine the difference of influence of the implementation of learning model of assisted advance organizer and post organizer expository. The population in this study is all students of class X MIA SMA Negeri 3 Mataram academic year 2017/2018. Sampling is done by purposive sampling technique, and quasi experimental research uses nonequivalent control group design with pre-test-and post-test. The results obtained from the classroom given the treatment of expository learning model assisted by advance organizer and post organizer have the same tendency improvement. In both classes there is a relatively similar increase in the mastery of the previous concept, but the difference between the two is not much different. Therefore, there is no difference of influence between expository model of assisted advance organizer and post organizer to the mastery of work and energy concepts of learners.
\end{abstract}

Keywords: expository learning model, concept mastery, advance organizer, post organizer.

\section{PENDAHULUAN}

Pengetahuan alam secara luas terkait disiplin Ilmu Pengetahuan Alam (IPA) merupakan pengetahuan yang bersifat sistematis dan tersusun dengan menggabungkan gejala-gejala maupun fenomena-fenomena yang terjadi di alam. Fisika pada hakikatnya memiliki karakteristik sebagai proses, produk dan sikap. Fisika sebagai proses merupakan serangkaian proses ilmiah yang dilakukan dalam menemukan pengetahuan tentang fisika. Sari et al, (2016) menyatakan bahwa fisika sebagai produk berarti fisika dipandang sebagai kumpulan-kumpulan pengetahuan yang berupa fakta, konsep, generalisasi, prinsip, teori dan hukum fisika. Sementara fisika sebagai sikap artinya bahwa penyampaian pendapat serta ide-ide melalui sikap ilmiah dalam suatu proses fisika digunakan untuk menghasilkan produk fisika (Muammar et al, 2015).

Guru-guru di sekolah lebih banyak menekankan pelajaran fisika sebagai produk sehingga peserta didik mengalami kesulitan untuk menguasai konsep fisika dengan baik. Berdasarkan hasil observasi, rendahnya hasil belajar fisika patut diduga karena lemahnya penguasaan konsep dimana peserta didik belum memiliki kemampuan untuk memahami dan mengaplikasikan konsep fisika yang digunakan untuk memecahkan masalah dalam kehidupan sehari-hari. Berdasarkan permasalahan tersebut maka diperlukan model pembelajaran yang dapat menghubungkan pengetahuan yang sudah dimiliki dengan pengetahuan baru sehingga dapat meningkatkan penguasaan konsep dengan menerapkan model pembelajaran ekspositori.

Model pembelajaran ekspositori merupakan model pembelajaran yang menekankan kepada penyampaian materi secara verbal dari seorang guru kepada sekelompok peserta didik dengan perpaduan matode ceramah, tanya jawab dan penugasan agar dapat menguasai materi pelajaran secara optimal. Sagala (dalam Harjono et al, 2018) menyatakan bahwa pembelajaran ekspositori menyajikan materi 
pelajaran secara utuh atau meyeluruh, lengkap dan sistematis sehingga sering disebut dengan metode ceramah atau konvensional. Dibandingkan model pembelajaran dengan ceramah, dominasi guru dalam model pembelajaran ini sudah banyak berkurang. Kegiatan guru berbicara hanya dilakukan pada saat-saat tertentu saja seperti pada awal kegiatan pembelajaran, menerangkan materi dan membimbing peserta didik dalam memahami materi serta memberi contoh soal. Hal ini sejalan dengan temuan Atriyanto \& Sulistyo (2014) bahwa dengan model pembelajaran ini peserta didik dapat merespon dengan baik pelajaran dan mendapat kesan serta pemahaman materi dengan sangat baik sehingga menunjang kemudahan untuk belajar. Harjono (2012) menyatakan model pembelajaran ini berlangsung melalui beberapa tahap, yaitu penyajian informasi, tes penguasaan dan penyajian ulang, memberikan kesempatan penerapan informasi baru dalam bentuk contoh dan soal dengan tingkat kesulitan yang bertambah serta memberikan kesempatan penerapan informasi baru dalam situasi dan masalah sebenarnya. Melalui model pembelajaran ini, guru dapat menyampaikan materi pembelajaran secara terstruktur dengan harapan materi pembelajaran yang disampaikan dapat dikuasai oleh peserta didik dengan baik.

Model pembelajaran ekspositori agar menjadi pembelajaran yang bermakna diberikan bantuan berupa organizers. Joyce et al, (2015) menyatakan organizers yang berarti pengaturan sangat terkait dengan materi yang mendahuluinya. Organizers yang diberikan dalam penelitian ini ada dua bentuk yakni advance organizer (AO) dan post organizer (PO). Ausubel (1968) mendeskripsikan AO sebagai materi pendahuluan yang ditampilkan di awal pembelajaran untuk membantu peserta didik membedakan materi baru dengan materi yang sudah dipelajari. Materi pengantar dalam bentuk AO disediakan oleh guru untuk membantu menghubungkan ke materi baru yang akan dipelajari. Amanah et al, (2017) menyatakan bahwa penggunaan AO berpengaruh terhadap peningkatan kemampuan pemecahan masalah fisika. AO yang disajikan di awal pembelajaran sangat membantu peserta didik untuk lebih mudah dalam menemukan masalah dan ide melalui peta konsep. Harjono (2012) juga mengungkapkan bahwa pemberian AO dapat meningkatkan hasil belajar yang lebih tinggi dibandingkan tanpa pemberian AO. Pemberian AO adalah salah satu fasilitas untuk mendapatkan pembelajaran bermakna jika pengetahuan lama relevan dengan pengetahuan baru.

Selain AO, bantuan berupa PO diduga dapat membantu peserta didik dalam belajar. Istilah PO digunakan untuk merujuk pada informasi yang diberikan kepada peserta didik setelah proses pembelajaran yang dapat menghubungkan apa yang baru saja dipelajari dengan latar belakang pengetahuan yang telah dimiliki sebelumnya. Chung et al, (2010) menyatakan pengetahuan yang lebih tinggi diperoleh dengan penerapan PO menghasilkan tidak hanya kemampuan daya ingat yang lebih tinggi namun juga dapat meningkatkan keefektifan dan keseriusan dalam pembelajaran. Penelitian Butz et al, (2005) menunjukkan perilaku pengajaran yang efektif dikombinasikan dengan tinjauan PO selama 15 menit bermanfaat untuk meningkatkan pengetahuan peserta didik.

Patut diduga dengan menggunakan model pembelajaran ekspositori berbantuan AO dan PO diharapkan dapat meningkatkan penguasaan konsep usaha dan energi peserta didik. Selain itu, belum banyaknya penggunaan model pembelajaran ekspositori berbantuan AO dan PO yang diterapkan di sekolah untuk mata pelajaran fisika sehingga peneliti merasa tertarik untuk melakukan 
penelitian. Penerapan model pembelajaran ekspositori berbantuan AO dan PO diduga tepat untuk digunakan di SMAN 3 Mataram. Hal tersebut didukung dari hasil observasi awal pada sekolah tersebut. Peneliti berharap penggunaan model pembelajaran ekspositori berbantuan AO dan PO dapat meningkatkan penguasaan konsep usaha dan energi peserta didik di tingkat sekolah menengah atas.

\section{METODE PENELITIAN}

Desain penelitian kuasi eksperimen ini menggunakan non-equivalent control group. Suatu penelitian memiliki beberapa variabel penelitian sehingga pembaca dapat mengetahui alur dari sebuah penelitian. Penelitian ini melibatkan variabel bebas yaitu model pembelajaran ekspositori, advance organizer dan post organizer, variabel terikat yaitu penguasaan konsep usaha dan energi, dan variabel kontrol yaitu alokasi waktu, guru yang mengajar dan materi ajar.

Penelitian ini dilakukan di SMAN 3 Mataram. Populasi penelitian adalah 6 kelas. Sampel penelitian adalah 72 peserta didik yang dibagi dalam dua kelas yaitu masingmasing 36 peserta didik untuk kedua kelas. Pemilihan sampel ditentukan dengan purposive sampling, dimana harus ada alasan khusus dalam pengambilan sampel. Alasan peneliti mengambil kelas X MIA 1 dan kelas X MIA 2 sebagai sampel karena memiliki jumlah peserta didik yang sama, data nilai hasil belajar fisika yang hampir sama serta peneliti sebelumnya sudah mengajar di kedua kelas tersebut sehingga mengetahui karakteristik dari peserta didik pada kedua kelas tersebut.

Instrumen yang digunakan adalah tes penguasaan konsep. Teknik pengumpulan data berupa tes tertulis berbentuk soal pilihan ganda. Tes penguasaan konsep berjumlah 20 soal. Indikator yang digunakan dalam tes penguasaan konsep ini mengacu pada taksonomi Bloom revisi ranah kognitif yang dilakukan oleh Anderson \& Krathwohl (2015) sebagai berikut. (1) Mengingat, (2) Memahami, (3) Mengaplikasikan, Menganalisis, (5) Mengevaluasi, dan (6) Mencipta. Instrumen tes penguasaan konsep sebelum digunakan harus memenuhi beberapa syarat yaitu uji validitas, reliabilitas, tingkat kesukaran dan daya beda soal. Uji analisis data menggunakan uji-t polled varians dengan taraf signifikan 5\% dan derajat kebebasan $\left(n_{1}+n_{2}\right)-2$. Data hasil penguasaan konsep yang diperoleh dianalisis dengan uji $\mathrm{N}$-gain untuk mengetahui peningkatan sebelum dan sesudah perlakuan antara kedua kelas.

\section{HASIL DAN PEMBAHASAN}

Penelitian dilakukan dengan memberikan perlakuan berupa penerapan model pembelajaran ekspositori berbantuan advance organizer (AO) pada kelas ekspositori berbantuan AO (X MIA 1) dan perlakuan berupa penerapan model pembelajaran ekspositori berbantuan post organizer (PO) pada kelas ekspositori berbantuan PO (X MIA 2). Kedua kelas diberikan perlakuan selama tiga kali pertemuan dengan alokasi waktu setiap pertemuan selama 135 menit (3 jam pelajaran). Sebelum diberikan perlakuan kedua kelas diberikan tes awal penguasaan konsep yang bertujuan untuk mengetahui kemampuan awal peserta didik pada kedua kelas.

Tes penguasaan konsep pada penelitian ini bertujuan untuk mengetahui perbedaan pembelajaran fisika menggunakan model pembelajaran ekspositori berbantuan AO dan PO yang diukur pada ranah kognitif C1 sampai C6. Data tentang hasil penguasaan konsep peserta didik sebelum dan sesudah perlakuan diperoleh peneliti melalui tes awal dan tes akhir. 
Kemampuan awal penguasaan konsep peserta didik baik kelas ekspositori berbantuan AO maupun kelas ekspositori berbantuan PO berdasarkan hasil tes awal masih rendah. Hal ini terlihat dari nilai ratarata tes penguasaan konsep masing-masing kelas, yaitu untuk kelas ekspositori berbantuan AO adalah 26,14 dan untuk kelas ekspositori berbantuan PO adalah 27,10, dan jika dibandingkan dengan nilai KKM, ratarata tersebut dikategorikan tidak tuntas. Hal ini disebabkan karena kurangnya kemampuan awal peserta didik untuk menghubungkan materi baru dengan materi dasar yang sebelumnya sudah diperoleh, sehingga solusi yang diterapkan oleh peneliti adalah melaksanakan pembelajaran menggunakan model pembelajaran ekspositori berbantuan AO dan PO.

Tes penguasaan konsep yang digunakan adalah tes pilihan ganda yang terdiri dari 20 soal. Adapun deskripsi statistik meliputi rata-rata, standar deviasi, varian, dan jumlah peserta didik berdasarkan pembelajaran yang digunakan dan ranah yang dinilai, yaitu ranah kognitif, maka yang diukur adalah penguasaan konsep peserta didik. Pengambilan data untuk data kemampuan awal dan akhir dilakukan dengan memberikan tes, yaitu tes awal dan tes akhir. Pada hasil uji coba instrumen terdapat 20 soal yang diterima, terdapat 20 soal yang valid dan reliabel. Peneliti menyimpulkan untuk mengambil 20 soal tersebut untuk diberikan ke peserta didik pada saat melakukan tes awal dan tes akhir.

Hasil penelitian yang sudah dilakukan menggambarkan bahwa kemampuan akhir penguasaan konsep peserta didik berbeda dengan kemampuan awalnya. Kelas ekspositori berbantuan AO maupun kelas ekspositori berbantuan PO mengalami peningkatan. Peningkatan kelas ekspositori berbantuan PO lebih tinggi daripada peningkatan pada kelas ekspositori berbantuan AO, namun perbedaan peningkatannya tidak jauh berbeda, sehingga dapat dikatakan bahwa model pembelajaran ekspositori berbantuan $\mathrm{AO}$ dan PO sama-sama berhasil meningkatkan penguasaan konsep usaha dan energi peserta didik dengan sangat baik. Pada kegiatan pembelajaran kelas ekspositori berbantuan AO dan PO terkandung lima sintaks, yaitu persiapan, penyajian, korelasi, menyimpulkan, dan mengaplikasikan. Kelima sintaks dalam pembelajaran ini terkandung dalam kegiatan pembelajaran yang dilakukan. Kelas ekspositori berbantuan AO mendapat bantuan peta konsep di awal pembelajaran agar memudahkan peserta didik menghubungkan ke materi baru yang akan dipelajari. Bantuan pada kelas ekspositori berbantuan PO yaitu berupa peta konsep yang diberikan di akhir pembelajaran atau setelah menerima materi pembelajaran sehingga peserta didik dapat membuat kesimpulan serta menghubungkan dengan materi sebelumnya yang sudah diperoleh. Kedua hal tersebut ternyata sangat efektif dalam meningkatkan penguasaan konsep usaha dan energi peserta didik.

Perbedan dari perlakuan dapat diketahui dengan menggunakan uji $t$. Sebelum melakukan uji-t pada hasil tes awal dan tes akhir, dilakukan terlebih dahulu uji normalitas dan uji homogenitas. Uji ini dilakukan bertujuan utuk memperoleh sampel yang terdistribusi normal, yaitu untuk uji normalitas dan uji homogenitas bertujuan untuk mengetahui apakah varians kelas ekspositori berbantuan AO dan kelas ekspositori berbantuan PO homogen.

Peningkatan signifikan pada tes akhir kelas ekspositori berbantuan AO yang menggunakan bantuan peta konsep ditunjukkan dari hasil tes penguasaan konsep. Pada hasil penelitian data penguasaan konsep diperoleh rata-rata kelas ekspositori berbantuan AO yaitu 61,29 dengan nilai tertinggi 80,00 dan nilai 
terendah 45,00. Nilai rata-rata tes awal dengan tes akhir penguasaan konsep sangat jauh berbeda yaitu dari 26,14 menjadi 61,29. Hal tersebut menunjukkan bahwa perlakuan yang diberikan pada kelas ekspositori berbantuan AO yang menggunakan bantuan peta konsep berdampak positif terhadap peningkatan penguasaan konsep usaha dan energi. Hasil ini sejalan dengan penelitian Amelia et al, (2016) membuktikan bahwa model pembelajaran AO dapat meningkatkan pemahaman konsep fisika. Hal ini dapat dilihat dari kegunaan peta konsep yang mempermudah peserta didik memahami hubungan antar konsep karena peta konsep meringkas materi dengan memperlihatkan hubungan antar konsep dan membantu mengingat materi baru. Harjono (2012) juga menunjukkan bahwa pemberian AO meningkatkan hasil belajar yang lebih tinggi dibandingkan tanpa pemberian AO. Pemberian AO adalah salah satu fasilitas untuk mendapatkan pembelajaran bermakna jika pengetahuan lama relevan dengan pengetahuan baru.

Kelas ekspositori berbantuan PO memperoleh nilai rata-rata sebesar 62,26 dengan nilai tertinggi 75,00 dan nilai terendah 45,00. Nilai rata-rata tersebut sangat berbeda dengan nilai pada tes awal yaitu 27,10. Nilai rata-rata tersebut menunjukkan bahwa ada peningkatan yang signifikan setelah kelas ekspositori berbantuan PO diberikan perlakuan berupa bantuan peta konsep, sehingga dapat diketahui bahwa PO berpengaruh positif terhadap peningkatan penguasaan konsep usaha dan energi peserta didik. Hasil penelitian ini sejalan dengan penelitian sebelumnya oleh Butz et al, (2005) yang menunjukkan bahwa pemberian post organizer (PO) bermanfaat untuk meningkatkan pengetahuan dan kemampuan daya ingat yang lebih tinggi. Romberg dan Wilson (dalam Peterson, 1971) menunjukkan adanya interaksi yang signifikan antara penyelenggaraan tingkat lanjut mengenai ingatan dalam konsep matematika, dimana AO dan PO masingmasing memberikan informasi untuk menghubungkan materi baru dengan struktur kognitif yang sudah ada atau mungkin dimiliki peserta didik yang akan memfasilitasi penyimpanan materi pelajaran yang disampaikan.

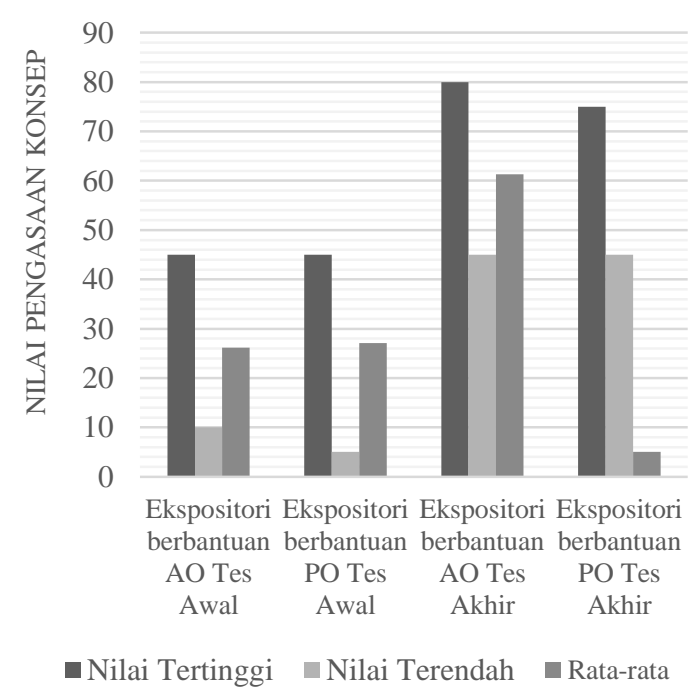

Gambar 1. Hasil Tes Penguasaan Konsep Pada Kedua Kelas

Gambar 1 menunjukkan perbedaan nilai tertinggi, nilai terendah dan nilai ratarata dari masing-masing kelas. Terlihat bahwa perbedaan antara nilai tertinggi dan nilai terendah antara kedua kelas tidak jauh berbeda. Rata-rata nilai tes penguasaan konsep antara kedua kelas juga tidak berbeda secara signifikan.

Pembelajaran yang berorientasi terhadap penguasaan konsep atau materi hanya berhasil untuk mengingat dalam jangka waktu yang pendek tetapi gagal untuk memecahkan masalah di kemudian hari. Pembelajaran fisika bukan hanya sekedar dapat menguasai sekumpulan pengetahuan yang berupa fakta, konsep, prinsip atau teori saja, tetapi proses belajar fisika akan lebih bermakna apabila peserta didik dapat mengalami sendiri apa yang mereka pelajari. Ausubel

(1968) 
menjelaskan pembelajaran bermakna adalah belajar yang disertai dengan pengertian dan akan terjadi apabila informasi yang baru diterima mempunyai kaitan yang erat dengan konsep yang sudah ada atau sudah diterima oleh peserta didik sebelumnya dan tersimpan dalam struktur kognitifnya. Pembelajaran bermakna menganjurkan pentingnya penguasaan konsep-konsep terutama dalam pembelajaran fisika yang tidak dapat dilepaskan dari hubungan antar konsep. Oleh karena itu, model pembelajaran ekspositori agar menjadi pembelajaran bermakna diberikan bantuan berupa organizer dalam bentuk advance organizer ( $\mathrm{AO})$ dan post organizer (PO). Hal tersebut dapat menjelaskan bahwa AO dan PO dapat membantu agar informasi lebih bermakna dengan menghubungkan pengetahuan sebelumnya dengan pengetahuan baru. Sejalan dengan hal tersebut AO mempunyai kemampuan pada transfer pengetahuan sedangkan PO mempunyai kemampuan mengingat kembali.

Setelah diuji, ternyata kedua kelas homogen dan terdistribusi normal baik pada tes awal maupun tes akhir, artinya kemampuan awal peserta didik pada kedua kelas tersebut sama, dan setelah diberi perlakuan yang berbeda data yang di dapat tetap homogen dan terdistribusi normal. Berdasarkan hasil tersebut dapat diketahui bahwa walaupun perlakuan yang diberikan pada kedua kelas tersebut berbeda, namun menunjukkan hasil yang relatif sama yaitu sama-sama memberikan peningkatan yang positif pada penguasaan konsep peserta didik. Kelas yang diberikan perlakuan menggunakan bantuan PO memiliki peningkatan yang lebih tinggi dibandingkan dengan kelas yang diberikan bantuan AO. Hal tersebut terjadi karena bantuan PO diberikan di akhir pembelajaran setelah peserta didik menerima materi dari guru sedangkan AO hanya diberikan di awal pembelajaran. Walaupun demikian, perbedaan peningkatannya tidak jauh berbeda sehingga dapat dinyatakan bahwa tidak ada pebedaan yang signifikan dari hasil peningkatan penguasaan konsep pada kedua kelas.

Perbedaan peningkatan penguasaan konsep pada kedua kelas terjadi karena peserta didik cenderung lebih baik dalam menguasai konsep-konsep fisika pada materi usaha dan energi ketika mereka mendapatkan bantuan di akhir pembelajaran atau setelah menerima materi dari guru. Apabila bantuan hanya diberikan di awal, hal tersebut cenderung membuat peserta didik akan sedikit kesulitan membuat kesimpulan dan mengingat materi pelajaran yang baru disampaikan. Namun, jika gambaran tersebut berupa peta konsep yang jelas dan runtut, peserta didik akan mendapatkan poin-poin penting dalam membuat kesimpulan dan mengingat materi pelajaran yang baru disampaikan tersebut. Pemberian PO setelah peserta didik mendapat materi pembelajaran dari guru ternyata sangat efektif karena dapat memperkuat kemampuan daya ingat dan membantu peserta didik menyimpulkan pembelajaran, sehingga baik $\mathrm{AO}$ ataupun PO memiliki dampak yang positif dalam meningkatkan penguasaan konsep peserta didik. Oleh karena itu, hasil penelitian ini menunjukkan perbedaan peningkatan yang tidak jauh berbeda antara kedua kelas. Kedua perlakuan ternyata memiliki dampak yang sama baiknya sehingga tidak ada perbedaan yang signifikan dari kedua perlakuan tersebut.

Setelah dilakukan uji hipotesis dengan menggunakan uji statistik (uji-t polled varians), didapatkan harga $t_{\text {hitung }}=$ 1,40454. Harga ini lebih kecil dari harga $t_{\text {tabel }}=1,99773$. Hal ini berarti tidak ada perbedaan penguasaan konsep antara peserta didik yang diberikan perlakuan berupa 
penerapan model pembelajaran ekspositori berbantuan AO dengan kelas yang diberikan perlakuan berupa penerapan model pembelajaran ekspositori berbantuan PO, sehingga terbukti bahwa tidak ada perbedaan dari kedua perlakuan tersebut.

Materi usaha dan energi dalam penelitian ini dibatasi pada 6 sub materi, yaitu konsep usaha (sub 1), energi kinetik (sub 2), energi potensial (sub 3), daya (sub 4), gaya konservatif (sub 5), dan hukum kekekalan energi mekanik (sub 6) yang ditampilkan pada Gambar 2 berikut.

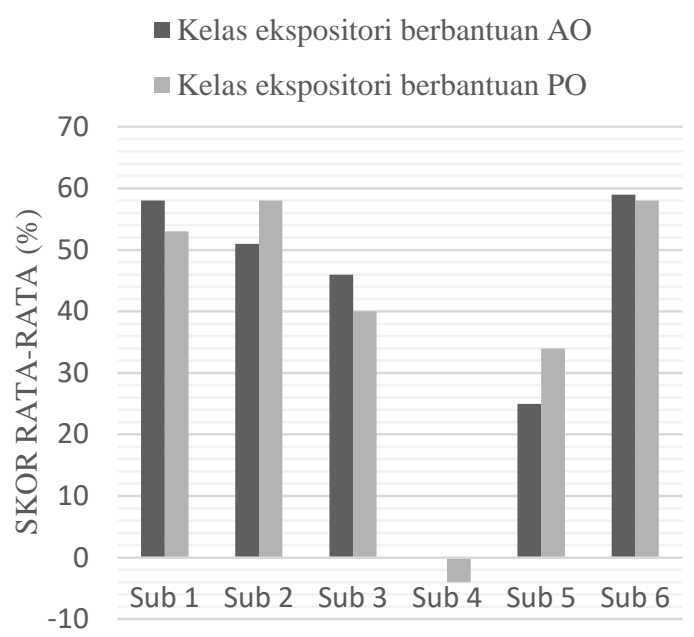

Gambar 2. Perbandingan Skor N-gain

Penguasaan Konsep tiap Sub Materi pada Kedua Kelas

Pada Gambar 2 diketahui bahwa terdapat perbedaan peningkatan penguasaan konsep setiap sub materi antara kelas ekspositori berbantuan AO dan kelas ekspositori berbantuan PO. Peningkatan tertinggi pada kelas ekspositori berbantuan AO dan kelas ekspositori berbantuan PO terdapat pada materi hukum kekekalan energi mekanik sebesar 58\% dan 59\%, keduanya berada pada kategori sedang.

Peningkatan tertinggi pada sub materi hukum kekekalan energi mekanik sangat dikuasai oleh peserta didik karena dalam kegiatan pembelajaran fokus perhatian peserta didik untuk belajar lebih meningkat lagi. Hal ini disebabkan rasa ingin tahu yang tinggi pada diri peserta didik untuk dapat memahami materi hukum kekekalan energi mekanik dengan baik karena pada kegiatan pembelajaran di tahap mengaplikasikan lebih banyak waktu untuk membahas soal-soal terkait materi ini yang hampir selalu keluar dalam soal ujian nasional. Selain itu, materi hukum kekekalan energi mekanik sebagai materi terakhir mencakup beberapa materi lainnya seperti energi potensial dan energi kinetik yang sudah dipelajari pada kegiatan pembelajaran sebelumnya.

Peningkatan terendah pada kelas ekspositori berbantuan AO dan kelas ekspositori berbantuan PO terdapat pada materi daya dimana pada kelas ekspositori berbantuan AO peningkatan penguasaan konsep sebesar $0 \%$ yang artinya sama sekali tidak ada peningkatan, sedangkan pada kelas ekspositori berbantuan PO terjadi penurunan tingkat penguasaan konsep peserta didik sebesar 4\%. Rendah dan menurunnya tingkat penguasaan konsep ini karena pada materi daya peserta didik mengalami kesulitan untuk menghubungkan konsep daya dengan konsep usaha-energi sehingga tidak dapat menyelesaikan soal terkait materi daya dengan baik dan benar. Faktor lainnya disebabkan karena pada buku pelajaran yang dimiliki oleh peserta didik tidak terdapat materi tentang konsep daya sehingga hanya mendapat penjelasan dari guru tentang materi daya ini. Hasil analisis peningkatan penguasaan konsep usaha dan energi yang ditinjau pada aspek kognitif $\mathrm{C} 1$ hingga C6 juga mengalami peningkatan yang cukup signifikan

Gambar 3 menjelaskan bahwa secara keseluruhan penguasaan konsep kelas ekspositori berbantuan AO dan kelas ekspositori berbantuan PO sama-sama mengalami peningkatan. Peningkatan tertinggi terdapat pada aspek kognitif C5 (mengevaluasi). Hal ini disebabkan karena instrumen untuk aspek kognitif ini sebelumnya sudah diberikan dalam bentuk 
contoh dan latihan soal pada kegiatan pembelajaran. Hasil penelitian ini menunjukkan bahwa model pembelajaran ekspositori pada kelas ekspositori berbantuan AO dan kelas ekspositori berbantuan PO mampu meningkatkan penguasaan konsep yang lebih tinggi di setiap aspek kognitifnya, sedangkan peningkatan terendah terdapat pada aspek kognitif C2 yaitu memahami. Hal ini dikarenakan peserta didik masih mengalami kesulitan dalam membangun makna atau pengertian dari soal yang diberikan pada saat tes sebab soal yang diberikan berbeda dari contoh dan latihan soal yang sudah diberikan sebelumnya pada kegiatan pembelajaran.

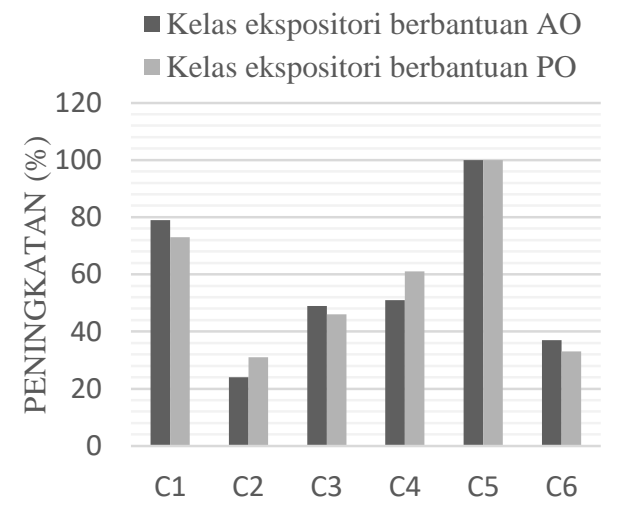

Gambar 3. Perbandingan Skor N-Gain Aspek Ranah Kognitif pada Kedua Kelas

Temuan penelitian oleh Amanah et al, (2017) yang menunjukkan bahwa penggunaan AO mampu memfasilitasi peserta didik dalam meningkatkan kemampuan pemecahan masalah fisika. Penggunaan AO yang disajikan di awal pembelajaran sangat membantu peserta didik untuk lebih mudah dalam menemukan masalah dan ide melalui peta konsep. Amelia et al, (2016) membuktikan bahwa model pembelajaran AO dapat meningkatkan pemahaman konsep fisika. Hal ini dapat dilihat dari kegunaan peta konsep yang mempermudah peserta didik memahami hubungan antar konsep karena peta konsep meringkas materi dengan memperlihatkan hubungan antar konsep dan membantu mengingat materi baru. Harjono (2012) juga menyatakan bahwa pemberian AO meningkatkan hasil belajar yang lebih tinggi dibandingkan tanpa pemberian AO. Pemberian AO adalah salah satu fasilitas untuk mendapatkan pembelajaran bermakna jika pengetahuan lama relevan dengan pengetahuan baru. Hasil penelitian ini juga sejalan dengan penelitian Hasbiyalloh et al, (2017) yang menyebutkan bahwa model pembelajaran ekspositori berbantuan $\mathrm{AO}$ memberikan pengaruh positif terhadap peningkatan hasil belajar fisika peserta didik. Butz et al, (2005) dan Chung et al, (2010) menyatakan pemberian PO bermanfaat untuk meningkatkan pengetahuan dan kemampuan daya ingat yang lebih tinggi sehingga dalam penelitian ini pemberian bantuan PO dalam penerapan model pembelajaran ekspositori memiliki nilai rata-rata yang lebih tinggi dibandingkan dengan pemberian bantuan AO. Peneliti mempredikasi bahwa PO sebagai bantuan yang diberikan di kegiatan akhir pembelajaran sangat efektif bagi peserta didik untuk menyimpulkan pembelajaran dan meningkatkan kemampuan daya ingat guna memfasilitasi penyimpanan materi pembelajaran secara optimal. Berdasarkan temuan penelitian ini dan temuan penelitian lain oleh Romberg dan Wilson (dalam Peterson, 1971) menunjukkan adanya interaksi yang signifikan antara penyelenggaraan tingkat lanjut mengenai ingatan dalam konsep matematika, dimana AO dan PO masingmasing memberikan informasi untuk menghubungkan materi baru dengan struktur kognitif yang sudah dimiliki peserta didik yang akan memfasilitasi penyimpanan materi pelajaran yang disampaikan. Penelitian tersebut membuktikan penggunaan model pembelajaran ekspositori berbantuan advance organizer dan post organizer berpengaruh positif terhadap 
penguasaan konsep usaha dan energi peserta didik kelas X.

Berdasarkan teori dan temuan dalam penelitian ini dapat dinyatakan bahwa model pembelajaran ekspositori berbantuan organizers dalam bentuk AO dan PO dapat membantu agar informasi lebih bermakna dengan menghubungkan pengetahuan sebelumnya dengan pengetahuan baru. Sejalan dengan hal tersebut AO mempunyai kemampuan pada transfer pengetahuan sedangkan PO mempunyai kemampuan mengingat kembali. AO sangat berguna pada transfer pengetahuan sesuai dengan pendapat Ausubel (1968) yang menyatakan bahwa seseorang memperoleh pengetahuan terutama melalui penerimaan bukannya melalui penemuan. Semakin terorganisir materi dalam bentuk AO yang disampaikan, maka peserta didik akan mempelajarinya secara keseluruhan serta dapat meningkatkan kejelasan yang dapat diserap sehingga dapat menerima materi pembelajaran secara maksimal. AO dirancang untuk memperkuat struktur kognitif peserta didik mengenai pengetahuan tentang pelajaran tertentu dan bagaimana mengelola, memperjelas, dan memelihara pengetahuan dengan baik. PO yang mempunyai kemampuan untuk mengingat kembali sangat bermanfaat untuk menanamkan belajar menerima yang bermakna, dimana materi pelajaran yang telah tersusun disampaikan kepada peserta didik sampai bentuk akhir kemudian pengetahuan yang baru saja diterima dikaitkan dengan pengetahuan yang sudah dimiliki. PO mengarahkan peserta didik untuk dapat menyimpulkan materi pembelajaran dan menolong mereka untuk mengingat kembali informasi yang berhubungan sehingga dapat digunakan dalam membantu menanamkan pengetahuan baru.

\section{PENUTUP}

Berdasarkan hasil analisis data dan pembahasan, dapat disimpulkan bahwa tidak terdapat perbedaan penguasaan konsep usaha dan energi peserta didik antara yang diberikan perlakuan berupa model pembelajaran ekspositori berbantuan advance organizer dengan kelas yang diberikan perlakuan berupa model pembelajaran ekspositori berbantuan post organizer. Hal tersebut terjadi karena peningkatan penguasaan konsep usaha dan energi kedua kelas hampir sama. Kedua perlakuan yang diberikan ternyata memberikan dampak yang sama baiknya sehingga meningkatkan penguasaan konsep peserta didik. Alasan teoritis tidak adanya perbedaan penerapan model pembelajaran ekspositori berbantuan AO dan PO berdasarkan hubungan pengetahuan sebelumnya dengan pengetahuan baru agar pengetahuan yang diperoleh menjadi bermakna. Sejalan dengan hal tersebut AO mempunyai kemampuan pada transfer pengetahuan sedangkan PO mempunyai kemampuan mengingat kembali.

\section{REFERENSI}

Amanah, P. D., Harjono, A., \& Gunada, I. W. 2017. Kemampuan Pemecahan Masalah Dalam Fisika Dengan Pembelajaran Generatif Berbantuan Scaffolding dan Advance Organizer. Jurnal Pendidikan Fisika dan Teknologi. 3(1): 84-91.

Amelia, R., Mansyur, J., \& Kade, A. 2016. Pengaruh Model Pembelajaran Advance Organizer dengan Menggunakan Peta Konsep Terhadap Pemahaman Konsep Siswa Kelas X Di SMA Negeri 7 Palu. Jurnal Pendidikan Fisika Tadulako Online (JPFT). 4(2):17-22.

Anderson, L.W dan Krathwohl, D.R. 2015. Kerangka Landasan untuk Pembelajaran, Pengajaran, dan Asesmen: Revisi Taksonomi 
Pendidikan Bloom. Yogyakarta: Pustaka Pelajar.

Atriyanto, B dan Sulistyo, E. 2014. Pengaruh Strategi Pembelajaran Ekspositori Terhadap Hasil Belajar Siswa pada Mata Diklat Memperbaiki Compact Cassete Recorder Kelas XI TAV di SMA Negeri 2 Surabaya. Jurnal Pendidikan Teknik Elektro. 3(2): 913.

Ausubel, D.P. 1968. Educational Psychology: A Cognitive View. New York: Holt, Rinehart, and Winston.

Butz, J.A., Miller, S.P., \& Butz, C. 2005. Effect of Post-Organizers on Preservice Teachers' Content Knowledge and Understanding of Effective Teaching Behaviors. The Teacher Educator. 41(1): 1-15.

Chung, S. \& Cheon J. 2010. The Effects of Post Organizers in Game-Based Learning. Texas Tech University. 23(4): 17-20.

Harjono, A. 2012. Perbedaan Strategi Pembelajaran dan Pemberian Advance Organizer Pengaruhnya Terhadap Hasil Belajar Fisika Siswa Kelas X. Jurnal Pijar MIPA. 7(1): 13-17.

Harjono, A., Gunada, I. W., Sutrio, \& Hikmawati. 2018. Penerapan Advance Organizer dengan Model Pembelajaran Ekspositori Berpola Lesson Study Untuk Meningkatkan Hasil Belajar Fisika Peserta Didik. Jurnal Pendidikan Fisika dan Teknologi.4(1): 141-150.

Hasbiyalloh, A. S., Harjono, A., \& Verawati, N.N.S.P. 2017. Pengaruh Model Pembelajaran Ekspositori Berbantuan Scaffolding dan Advance Organizer Terhadap Hasil Belajar Fisika Peserta Didik Kelas X. Jurnal Pendidikan Fisika dan Teknologi. 3(2): 173-180.

Joyce, B., Weil, M., \& Calhoun, E. 2015. Models of Teaching Edisi
Kesembilan. Yogyakarta: Pustaka Pelajar.

Muammar, H., Harjono, A., \& Gunawan, G. 2015. Pengaruh Model Pembelajaran Assure dan Pengetahuan Awal Terhadap Hasil Belajar IPA-Fisika Siswa Kelas VIII SMPN 22 Mataram. Jurnal Pendidikan Fisika dan Teknologi. 1(3): 166-172.

Peterson, J. C. 1971. Effect of an Advanced Organizer, A Post Organizer, or Knowledge of a Behavioral Objective on Achievement and Retention of a Mathematical Concept. Annual Meeting of the American Educational Research Association: 1-20.

Sari, P. I., Gunawan, G., \& Harjono, A. 2016. Penggunaan Discovery Learning Berbantuan Laboratorium Virtual pada Penguasaan Konsep Fisika Siswa. Jurnal Pendidikan Fisika dan Teknologi. 2(4): 176-182. 